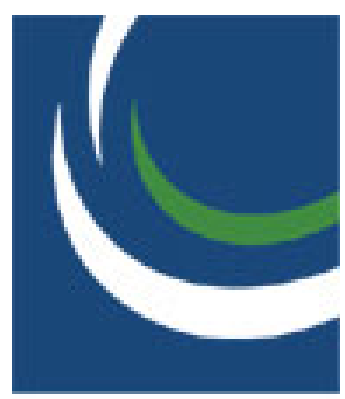

apsa

An Analysis of Congressional Career Decisions, 1947-1986

Author(s): D. Roderick Kiewiet and Langche Zeng

Source: The American Political Science Review, Vol. 87, No. 4 (Dec., 1993), pp. 928-941

Published by: American Political Science Association

Stable URL: http://www.jstor.org/stable/2938824

Accessed: 12/11/2014 22:52

Your use of the JSTOR archive indicates your acceptance of the Terms \& Conditions of Use, available at http://www.jstor.org/page/info/about/policies/terms.jsp

JSTOR is a not-for-profit service that helps scholars, researchers, and students discover, use, and build upon a wide range of content in a trusted digital archive. We use information technology and tools to increase productivity and facilitate new forms of scholarship. For more information about JSTOR, please contact support@ jstor.org.

American Political Science Association is collaborating with JSTOR to digitize, preserve and extend access to The American Political Science Review. 


\title{
AN ANALYSIS OF CONGRESSIONAL CAREER DECISIONS, 1947-1986
}

\author{
D. RODERICK KIEWIET California Institute of Technology \\ LANGCHE ZENG University of Oregon
}

\begin{abstract}
$M$ ost previous research on congressional career decisions has focused on one of two binary choices-between retiring and running for reelection, or between running for reelection and seeking higher office. But most of the time, representatives face all three choices simultaneously. Employing a "mother logit" model, we estimate the effects of relevant variables both on pairwise comparisons (conditional probabilities) and on the unconditional probabilities of choosing each one of these three alternatives. Probably most intriguing is our finding that a member's age has little or no effect upon the unconditional probability of running for reelection. The interrelatedness of career options is seen particularly clearly in the case of incumbents who had been redistricted out of their seats. When they had an opportunity to run for higher office, they were likely to take it. Only when they lacked such an opportunity were they more likely than other members to opt for retirement.
\end{abstract}

$\mathbf{R}$ esearch on congressional career decisions has largely followed two separate and independent paths. The first concerns the decisions of members of the House of Representatives either to run for reelection or to retire. Many of these studies have sought to explain major shifts in retirement rates over time-the upsurge in retirements that occurred during the 1970s (Cooper and West 1981; Frantzich 1978; Hibbing 1982), their subsequent decline in the 1980s (Moore and Hibbing 1991), and the jump of retirement rates to record levels in 1992 (Groseclose and Krehbiel 1993; Jacobson and Dimock 1993). A second major area of inquiry focuses on the decision of House incumbents either to run for reelection or to abandon their seats in order to seek higher officetypically governor or U.S. senator. Adopting the terminology of Schlesinger's (1966) classic study, the latter choice is referred to as progressive ambition. In seeking to explain voluntary departure from the House, most previous studies of congressional career decisions have thus treated these decisions as simple binary choices: (1) retire or not and (2) seek higher office or not.

Most of the time, however, congressmen actually face all three choices-run for reelection, retire, or run for higher office-simultaneously. To examine retirements separately or progressive ambition separately artificially truncates the actual menu of choices that incumbents confront. This point is more than a conceptual or semantic one. Assume, for example, that a particular member has tired of service in the House. With an incumbent of his own party running for reelection in both the gubernatorial and senatorial races in his state, he decides to go back home and practice law. But what if the senate race were instead for an open seat? If he decided to abandon his House seat for a try at the Senate, that representative would be excluded from an analysis of voluntary retirements, because he chose neither to retire nor to run for reelection. Yet at least in this example, the member was as disenchanted of the House as any other retiree. Furthermore, when we see that at a particular point in time a member chooses to retire, we also know that they have not on some previous occasion decided to seek higher office-and vice versa. ${ }^{1}$

More precisely, previous studies of voluntary retirement were analyzing the conditional probability of members choosing retirement over seeking reelection, given that they had not otherwise chosen to run for higher office. Similarly, studies of progressive ambition were analyzing the conditional probability of seeking higher office versus remaining in the House, given that the member had not otherwise chosen to retire. We learn how a representative chooses from a subset of all possible alternatives but nothing about how the subset was chosen. One major consequence of not simultaneously examining all possible alternatives is a failure to specify relevant variables that enter the choice calculation. For example, previous studies of voluntary retirement have not considered the impact of key variables that affect progressive ambition, such as the desirability of another office and the likelihood of obtaining it. True, these variables probably do not affect the conditional probability of retiring versus seeking reelection. If they increase the probability of House members seeking higher office, however, they necessarily decrease the probability of members choosing the choice subset of $\{$ retire, reelection $\}$ and thus necessarily decrease the probability of retiring.

We shall formulate an integrated model of congressional career decisions, a model based upon the assumption of expected utility maximization. After a discussion of our estimation strategy, we review the two strands of research identified previously-progressive ambition and voluntary retirement-in order to identify key variables needed to enter into our model. The data used in our analysis are the career decisions made by incumbents serving in the House from the Eightieth through the Ninety-ninth Congresses (1947-86). Following the lead of previous research, we first estimate the effect of key variables upon each pairwise comparison of choices. However, we then calculate the effect of each significant inde- 
pendent variable upon the unconditional probability of choosing each of the three alternatives run for reelection, seek higher office, or retire. Our intention here is to draw as complete a picture as possible of how House members choose among their career alternatives. An important contribution of this analysis is the information it reveals about those who choose to stay in the House. Over the past several years, the percentage of incumbents defeated in their reelection bids has usually been quite low (see Figure 1). To understand the composition of the House and turnover in its membership, it has thus become particularly important to understand why and when incumbents choose to leave the House voluntarily.

\section{AN EXPECTED-UTILITY ANALYSIS OF CONGRESSIONAL CAREER DECISIONS}

We assume that representatives are rational in the sense of maximizing expected utility. Consider the choices that House incumbents face at the end of each term. Those who have an opportunity to run for a higher office have the choice set $J=\left\{a_{1}, a_{2}, a_{3}\right\}$, where $a_{1}=$ retire, $a_{2}=$ run for reelection to the House, and $a_{3}=$ run for a higher office. Those who do not have an opportunity for higher office choose between $a_{1}$ and $a_{2}$. Rohde (1979) considers a House member to have such an opportunity if an election is being held in the member's state for a Senate seat or for the governorship and there is no own-party incumbent seeking reelection to the office in question. Given that House members virtually never challenge an incumbent governor or senator of their own party, this would appear to be an appropriate way to proceed.

Under the rationality assumption, a representative chooses option $a_{j}$ if and only if the expected utility of $a_{j}$ is greater than that of all other available options. The representative who chooses to retire receives the utility of retirement $U_{1}$ with certainty, that is, probability $Q_{1}=1$. The representative who chooses to run for reelection wins reelection with probability $Q_{2}$, receiving utility from the House seat $U_{2}$, minus the cost of running for reelection $C_{2}$ and, correspondingly, loses with probability $1-Q_{2}$, receiving $U_{1}-$ $\mathrm{C}_{2}$. The representative who chooses to run for higher office wins with probability $Q_{3}$, receiving utility from the higher office seat $U_{3}$ minus the cost of running for it $C_{3}$, and loses with probability $1-Q_{3}$, receiving $U_{1}-C_{3}$. Let $E_{j}$ denote the expected utility of choosing option $a_{j}$. Hence we have

$$
\begin{aligned}
E_{1} & =U_{1} \\
E_{2} & =Q_{2} U_{2}+\left(1-Q_{2}\right) U_{1}-C_{2} \\
& =U_{1}+Q_{2}\left(U_{2}-U_{1}\right)-C_{2} \\
E_{3} & =Q_{3} U_{3}+\left(1-Q_{3}\right) U_{1}-C_{3} \\
& =U_{1}+Q_{3}\left(U_{3}-U_{1}\right)-C_{3} .
\end{aligned}
$$

A graphical illustration of the choice situation presented in equation 1 is shown in Figure 2.

\section{FIGURE 1}

Sources of House Membership Turnover
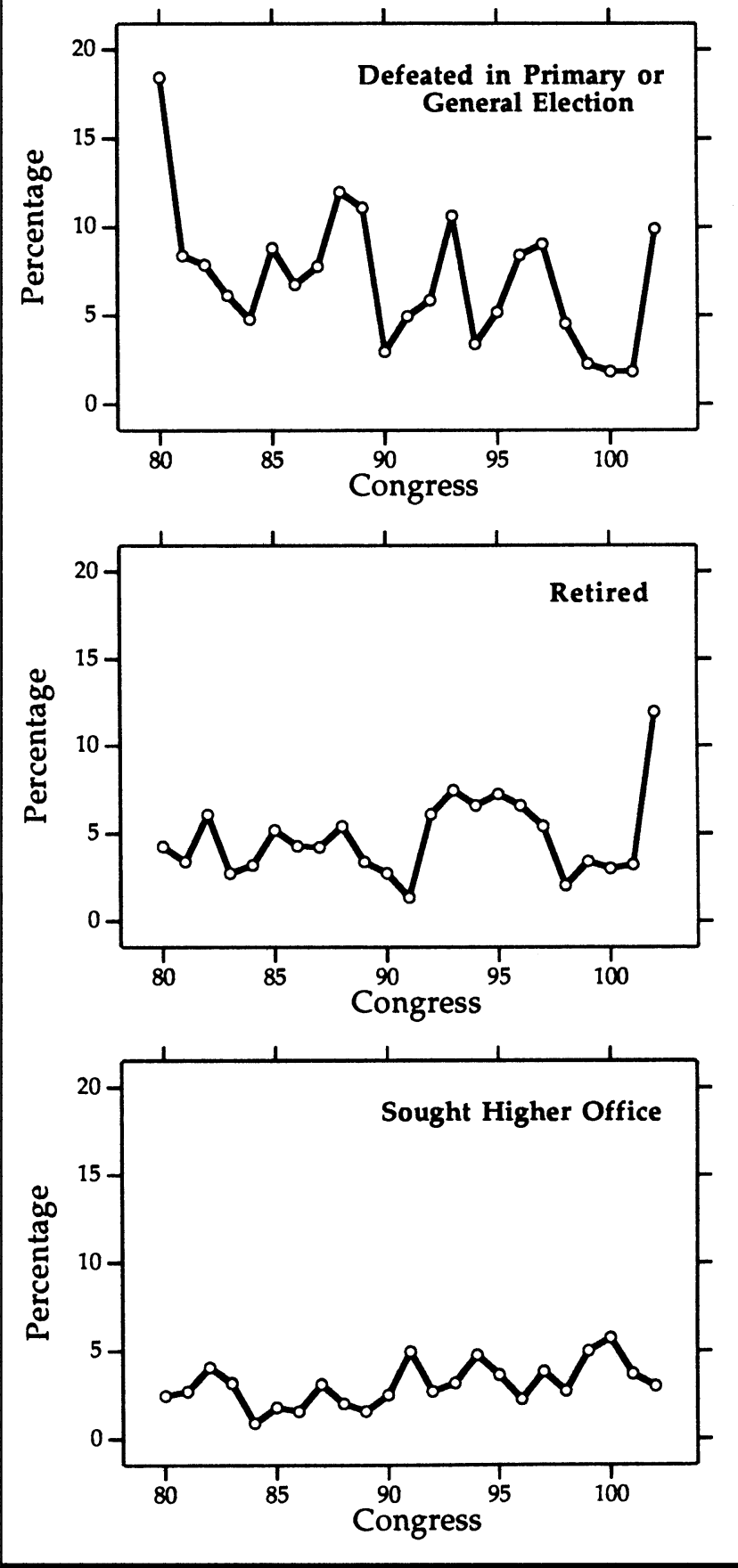

As any affine transformation of an expected utility function is also an expected utility function (Varian 1984), we can subtract $U_{1}$ from all $E_{j}$ and rewrite equation 1 as

$$
\begin{aligned}
& E_{1}=0 \\
& E_{2}=Q_{2}\left(U_{2}-U_{1}\right)-C_{2} \\
& E_{3}=Q_{3}\left(U_{3}-U_{1}\right)-C_{3} .
\end{aligned}
$$




\section{FIGURE 2}

Congressional Career Choices

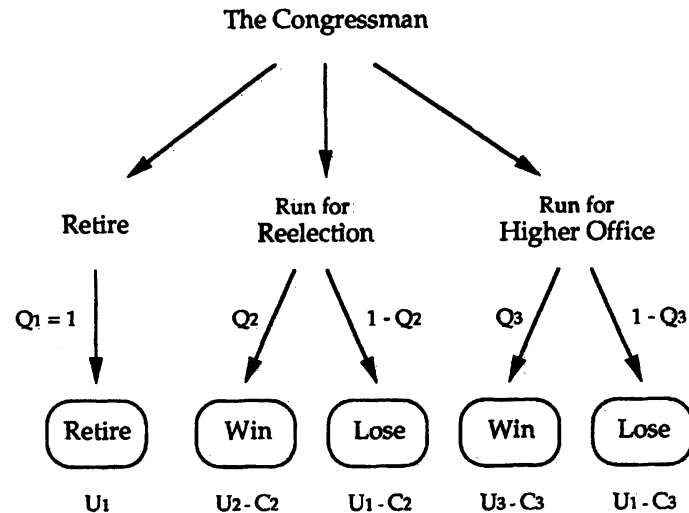

$$
\begin{aligned}
& E_{1}=U_{1} \\
& E_{2}=U_{1}+Q_{2}\left(U_{2}-U_{1}\right)-C_{2} \\
& E_{3}=U_{1}+Q_{3}\left(U_{3}-U_{1}\right)-C_{3}
\end{aligned}
$$

Now define $W_{i n}=\log P_{i n}^{*}$ and evaluate the logit probabilities based on $W_{i n}$ :

$$
P_{i n}-\frac{e^{W_{i n}}}{\Sigma_{j} e^{W_{j n}}}=\frac{e^{\log P_{i n}^{*}}}{\Sigma_{j} e^{\log P_{j n}^{*}}}=P_{i n}^{*},
$$

where the last equality is due to the fact that choice probabilities necessarily sum to 1 . Equation 3 shows that any choice probability $P_{i n}^{*}$ can be expressed in the logit probability form. ${ }^{2}$ The next question to consider is the appropriate specification of $W_{i}{ }^{3}$ Once we obtain $W_{i}$, we can straightforwardly estimate a logitform model. Because $W_{\text {in }}=\log P_{\text {in }}^{*}$ depends on the (expected) utilities of all alternatives, ${ }^{4}$ all variables that enter the utility function of any alternative enter each $W_{i n}$. For members facing different choice sets (i.e., with or without the option of seeking higher office), different sets of variables and coefficients may enter $W_{i}$. For those whose choice set does encompass all three alternatives, the expected utility function of equation 2 gives us

$$
W_{i}=g_{i}\left(U_{1}, U_{2}, U_{3}, Q_{2}, Q_{3}, C_{2}, C_{3}\right) \text {. }
$$

Let $X$ denote the vector of variables that appear in $g_{i}$ and assume, for simplicity, that $g_{i}$ s are linear, then $W_{i}=\beta_{i} X$ where $\beta_{\mathrm{i}}$ is a vector of coefficients. The choice probabilities are therefore given by

$$
P_{i}=\frac{e^{\beta_{i} X}}{\Sigma_{j=1}^{3} e^{\beta_{j} X}} .
$$

Equation 2 states that expected utility of running for reelection depends upon the probability of winning reelection, the cost of seeking reelection, and the value of a House seat relative to the value of retirement. Similarly, the expected utility of seeking higher office depends upon the probability of winning the higher office, the cost of seeking it, and the value of the higher office relative to the value of retirement.

If we knew the values of the $E_{j}$ s (i.e. the expected utilities associated with each choice), we could predict with certainty which one each representative would choose. Unfortunately, their exact values are functions of many variables, which are only partially observable or measurable. The model we estimate thus necessarily includes error, and predictions of choice can be made only in probabilistic terms. Our next task is thus to select a choice model giving the probabilities of choosing to retire, running for reelection, or seeking higher office, based upon the empirical expected utilities of the alternatives.

To avoid making strong assumptions about the nature of the errors in the Es, we adopt what has come to be called the mother logit model (McFadden 1975). As formulated by Train (1986), let $P_{i n}^{*}=f\left(z_{i n}\right.$; $z_{j n} \forall_{j} \neq i ; s_{n}$ ) be the "true" probability that decision maker $n$ chooses alternative $i$, where $z_{\text {in }}$ is the observed data relating to alternative $i$ faced by decision maker $n, z_{j n}$ is the observed data relating to alternatives other than $i$, and $s_{n}$ is a vector of characteristics associated with the decision maker. This model imposes no restrictions on the functional form of $f$. All choice models are special cases of this model, including the standard logit and probit models.
If the choice set contains two alternatives, then $U_{3}$, $Q_{3}$, and $C_{3}$ do not enter $W_{i}$. Denoting the rest of the variables by $Y$ and again assuming linearity, we have $W_{i}=\alpha_{i} Y$, where $\alpha_{i}$ is a vector of coefficients. The choice probabilities are therefore given by

$$
P_{i}=\frac{e^{\alpha_{i} Y}}{\Sigma_{j=1}^{2} e^{\alpha_{j} Y}} .
$$

Equation 4 can be rewritten as

$$
P_{1}=\frac{e^{\left(\beta_{1}-\beta_{2}\right) X}}{e^{\left(\alpha_{1}-\beta_{2}\right) X}+1+e^{\left(\beta_{3}-\beta_{2}\right) X}}
$$

or

$$
P_{1}=\frac{1}{1+e^{\left(\beta_{2}-\beta_{1}\right) X}+e^{\left(\beta_{3}-\beta_{1}\right) X}}
$$

$P_{2}$ and $P_{3}$ (and the probabilities in equation 5) can as the base of normalization, estimation of the model will give $\beta_{2}-\beta_{1}$ and $\beta_{3}-\beta_{1}$. We correspondingly estimate $\beta_{1}-\beta_{2}$ and $\beta_{3}-\beta_{2}$ if the second alternative is taken as the base of normalization and $\beta_{1}-\beta_{3}$ and $\beta_{2}-\beta_{3}$ if the third alternative is the base. Normalizing utilities using different bases can facilitate the interpretation of estimation results.

In the case of individuals with only two choices available, it is easy to verify that be expressed similarly. If the first alternative is taken 


$$
\frac{\partial P_{1}}{\partial Y}=P_{1} P_{2}\left(\alpha_{1}-\alpha_{2}\right)
$$

The variables are signed by $\alpha_{1}-\alpha_{2}$. Hence we can infer the direction of the effect upon $P_{1}$ of an independent variable $y$ directly from the sign of the estimated coefficient of $y$. If there are three alternatives, then

$$
P_{1}=\frac{e^{\beta_{1} X}}{\sum_{j=1}^{3} e^{\beta_{j} X}}=\frac{e^{\beta_{1} X}}{\sum_{j=1}^{2} e^{\beta_{j} X}} \frac{\Sigma_{j=1}^{2} e^{\beta_{j} X}}{\sum_{j=1}^{3} e^{\beta_{j} X}},
$$

where the second fraction is the probability of choosing the subset $\{1,2\}$ and the first fraction is the conditional probability of choosing alternative 1 over alternative 2 given that the subset $\{1,2\}$ is chosen. This conditional probability has the same functional form as the unconditional probability in the binary choice case, and similar analysis shows that its partial derivatives are signed by $\left(\beta_{1}-\beta_{2}\right)$.

\section{FACTORS INFLUENCING CONGRESSIONAL CAREER DECISIONS}

In order to analyze congressional career decisions within the framework of the model just developed, we need to identify variables that enter the vector $X$ (i.e., that affect the expected utility of competing career choices). The probability term associated with the retirement option $Q_{1}$ is of course always 1 , and this option entails no costs in selecting it. The variable most frequently associated with $U_{1}$-the value of retirement-is the member's age. Without exception, previous studies in this area observe a positive relationship between age and rates of retirement. Although members who retire from Congress do not necessarily exit the labor force entirely, it is quite to be expected that advancing years induce members to give up a job that is physically, mentally, and emotionally demanding. True, we could also view age as decreasing $U_{2}$, the value of remaining in the House. Whatever the case, age should act to lower the utility of continuing to serve in the House relative to that of retirement.

Turning next to $U_{2}$, perhaps the first variable that comes to mind is the salary that members are paid. Hibbing (1982) reports some evidence that increases in congressional salaries are associated with a decline in the number of retirements, and the wide variation in salary levels among different state legislatures clearly accounts for much of the variation in the degree of careerism present in the membership (Squire 1988). Unfortunately, in the U.S. Congress salary levels are the same for all members serving at the same time, change only infrequently, and as Hibbing observes are only one component of the total compensation package. Moreover, the relevant financial calculation incumbents need to make is not salary alone but rather the difference between their congressional salary and what can be earned on the outside in the form of wages or pensions or both. For these reasons, we think it best to focus on other, nonfinancial measures.

It is also probable that some members derive more utility from serving in the House than do others, as power and influence in the House are not uniformly distributed. Most previous studies use members' seniority rankings as an indicator of their place in the House hierarchy, the hypothesis being that more senior members of the House are more powerful and thus less inclined to leave voluntarily. Unfortunately, seniority is highly correlated with age, which is hypothesized to have precisely the opposite effect upon retirement decisions. Another major problem with this variable is that what counts in Congress is not seniority rank on the floor but rather one's place in party or committee. In our view, then, it is those members who are chairmen of a standing committee or who hold a high rank in the party apparatus (i.e., Speaker, majority leader, or whip) who would be expected to place greater value on serving in the House and so be less likely to retire or to run for higher office.

A characteristic that many studies have identified as a major source of job dissatisfaction in the House is minority party status, which, since World War II, has almost always meant being a Republican. Earlier studies focused on party differences in voluntary retirement rates and report evidence of higher rates among House Republicans (Bullock 1972; Frantzich 1978). More recently, Gilmour and Rothstein (1993) and Schansberg (1992) stress that Republicans differ from Democrats in their greater propensity to seek higher office. The explanation given for these findings is that minority status implies meager influence upon policymaking and virtually no prospect of a committee or subcommittee chair.

A related hypothesis is that House conservatives, presumably due to ideological frustration, exhibit higher rates of voluntary departure. Frantzich (1978) reports some evidence for this in his analysis of congressional retirements between 1966 and 1974, but by not controlling for party membership, he may have only identified a greater propensity toward retirement of House Republicans. Hibbing (1982) examines this hypothesis by investigating whether or not Southern Democrats or those with high Conservative Coalition scores were more likely to decide to retire. ${ }^{5}$ His results are generally supportive, but coefficient estimates vary a good deal from equation to equation. A potential problem with the hypotheses that minority party status and conservative ideological tendencies are a source of dissatisfaction is that of rational expectations. In other words, Republican candidates for the House must surely know that their party is unlikely to command a majority. Other conservative candidates for the House surely know that if elected, they are not going to be in the ideological mainstream of the House or even of their party. It is thus not obvious that they should subsequently find minority party status or ideological dis- 
tinctiveness to be a source of frustration or job dissatisfaction.

Previous research also suggests that important political changes inside and outside of the House arena have turned what used to be a pleasant, rewarding experience into what one observer describes as the "awful empty life of a congressman" (Barnes 1988). There are many more votes (often on trivial matters), longer sessions, and increased committee work load. Keeping the job, moreover, requires more trips back and forth between Washington and the district, far more expensive campaigns, and coping with nasty, hard-to-please single-issue groups. Establishing exactly when the Golden Age of Congress ended is problematic, but most scholars point to the early 1970s, with the Subcommittee Bill of Rights, the revolt against the chairmen, and the general assault on the seniority norm seen as watershed events. To be sure, the fact that these reforms were adopted necessarily means that most House members at the time preferred them to the previous regime. Even if they were generally popular, however, the reforms could still have induced higher rates of voluntary departure among the minority of members who were injured by them. And even members who favored the reforms may have found that they made the option of leaving the House more attractive by reducing the payoffs members receive from continued service-by increasing the value of a subcommittee chairmanship vis-à-vis a committee chairmanship, for example.

Whatever the case, during the 1970s dozens of retiring representatives expressed varying degrees of resentment against these reforms, leading congressional scholars to conclude that these changes were largely responsible for the surge in voluntary retirements that took place at this time (Cooper and West 1981; Hibbing 1982). Similarly, Brace's (1984) probit analysis of progressive ambition indicates that House incumbents were more likely to abandon their seats and seek higher office after the advent of these reforms. In the equation he estimates, he tests this hypothesis by specifying a dummy variable that takes on the value of 1 for individuals serving in the Ninety-first and subsequent Congresses. A problem with this operationalization is that members elected to the House subsequent to the reforms presumably knew what they were in for, and their career decisions should therefore not be influenced by institutional changes that occurred prior to their arrival on Capitol Hill. Consistent with this reasoning is the fact that in the 1980s, the rate of voluntary retirements again declined, returning to the low levels that had been observed in the 1960s (Moore and Hibbing 1991). It is preferable, then, to posit that the effects of the House reforms should be confined to those members elected to the House prior to their implementation.

The next term we need to consider is $Q_{2}$, the probability that an incumbent will be successful in seeking reelection to the House. Previous researchers have hypothesized that members choose to leave voluntarily rather than take on another campaign entailing an unacceptably low prospect for success (Bullock 1972; Frantzich 1978). This is of course precisely what our model predicts, but the two measures that have typically been used to test this hypothesismargin of victory in the previous election and a dummy variable indicating that a member's district had been altered due to redistricting - are not without problems. As Mann (1978) and Jacobson (1987) point out, over the past few decades a member's margin in the previous election has become a farfrom-reliable predictor of performance in the next election. Bauer and Hibbing (1989) argue that Jacobson's key finding (i.e., a larger number of incumbents with previously safe electoral margins nonetheless losing the next election) is primarily due to a larger number of them being damaged by redistricting and by scandal (including Watergate). Even if an incumbent's margin of victory in the previous election is a reliable guide to future electoral prospects, however, this does not mean it is an important factor in their career decisions.

Cooper and West (1981), similarly, note that redistricting more often than not increases rather than decreases the electoral security of incumbents, and even when it is injurious the amount of damage may be inconsequential. Still, there are plenty of instances in which it is unambiguously clear that an incumbent's prospects for reelection have been substantially damaged by redistricting. This occurs when large portions of two or more districts are combined into one new district, or when a member's district is abolished completely. In such cases a member can win reelection only by running against and defeating another incumbent-a far more formidable task than defeating the weak, underfinanced challengers incumbents typically run against. Because of the abolition of at-large congressional districts and the constraints imposed by the Supreme Court's "oneperson, one-vote" rulings, incumbents have become considerably more vulnerable in the redistricting process. While 18 and 21 incumbents lost their districts in the Eighty-Second and Eighty-Seventh Congresses, respectively, in the Ninety-Second and Ninety-Seventh Congresses the corresponding totals were 53 and 30.

Besides being redistricted out of a seat, another serious blow that an incumbent representative can suffer is to be caught up in a scandal. Without question, serious charges of severe misconduct have led to the resignation or retirement of dozens of representatives over the years. Previous research indicates that fairly stringent criteria should be used in identifying House incumbents who are tainted by scandal. Peters and Welch (1980) show that lesser accusations (e.g., violations of campaign finance regulations, conflicts of interest, or cronyism in hiring) have little impact on vote totals, so that most incumbents who are targets of such charges have no difficulty winning reelection. We would thus confine our attention to House incumbents who have either been criminally indicted, or who have been charged with 
acts of ethical or sexual misconduct that are serious enough to capture national attention. By this definition, the total count of scandals in our data is 58 .

A variable that might seem to be a straightforward measure of $C_{2}$, the cost of running for reelection, is the amount of money representatives expend in their reelection bids. The problem is that most of what congressional candidates spend is other people's money, so that the real costs that candidates face are those of inducing individuals and organizations to contribute to them, as well as any political or ethical problems that flow from accepting these contributions. There is also a endogeneity problem, in that the amount of money candidates raise and spend depends upon how badly they want to keep the job. Indeed, we only observe expenditures made by candidates who have decided that the cost of running for reelection is low enough (and the value of the office is high enough) to warrant the effort. This latter problem might be finessed by lagging the campaign expenditures variable, but unfortunately previous expenditures are not all that good an indicator of current campaign expenditures. These same problems, of course, apply to campaign expenditures as a measure of the cost of seeking higher office.

The next term in the $X$ vector to consider is $U_{3}$, the value of higher office, which, with a few exceptions, is either a governorship or a seat in the U.S. Senate. In this case, of course, the previous research that we have to draw upon comes primarily out of the literature on progressive ambition. Rohde (1979), first of all, finds that House members are much more likely to seek a seat in the Senate than a governorship. He attributes this (correctly, we think) to the fact that senators serve longer terms than governors and are more likely to win reelection.

As in the literature on voluntary retirement, much attention here has also been focused upon the importance of age. As Schlesinger puts it, "A man can fail to advance in politics as much because he is the wrong age at the wrong time as because he is in the wrong office" $(1966,174)$. Schlesinger reports that between 1900 and 1958, most members elected to the House for the first time were in their late thirties. Most governors took office for the first time while in their late forties, and most senators in their early fifties-considerably younger, in other words, than the age at which most members typically retire from the House. The implication of these findings is that the option of abandoning one's seat in the House for a chance at higher office would seem to be more attractive for the relatively young. Hain hypothesizes explicitly that "the older a politician is ... the less likely he is to harbor ambitions to advance" (1974, 265).

Exactly how age enters potentially ambitious House members' utility calculations has never been well specified. Schlesinger suggests that those who enter politics at an early age are politically more ambitious, which is another way of saying that the increase in utility between their current office and the office they aspire to is especially large. In our view, a more plausible hypothesis regarding age is offered by Rohde (1979). He argues that younger members have typically served fewer terms than older members and are thus more inclined to seek a Senate seat or governorship because they have less to give up by way of power and seniority. In his probit analysis of progressive ambition among House members, Brace (1984) posits age to have a "curvilinear" effect, with both relatively young and relatively old members being less likely to pursue higher office. Because of the high degree of correlation between the age and age $^{2}$ terms needed to specify this effect, we think it is preferable to entertain the simpler hypothesis that increasing age, contrary to the role it plays in encouraging retirement, discourages House members from seeking higher office.

Previous studies of progressive ambition have been most thorough in analyzing $Q_{3}$, the probability of winning election to higher office. First, both Rohde (1979) and Brace (1984) find that House members are far more likely to run for an open seat than against an incumbent governor or senator of the opposing party. Both consider the prospect of challenging an incumbent senator or governor of one's own party as so uninviting that for all practical purposes it is no opportunity at all. That House members are more attracted to opportunities than entail a greater chance of success is further borne out by their finding that members from small states exhibit higher rates of progressive ambition than those from larger states. In the view of Rohde and Brace, this is due to the greater degree of commonality between their House district and the entire state. Rohde found this effect to be especially pronounced in states with just one or two congressional districts. We would add that large-state members contemplating a run for higher office confront a larger potential pool of formidable candidates-other House members like themselves. While the likelihood is high that a few will run anyway, many more will be discouraged.

\section{ANALYSIS AND FINDINGS}

Before estimating our mother logit model of congressional career decisions, we need to detail exactly how the variables discussed are operationalized and, where useful, briefly to reiterate our expectations as to their effects on congressional career decisions.

(1) Age should increase the probability of retirement to the extent that increasing age lowers the utility of remaining in office relative to that of retirement. We hypothesize age to be negatively associated with progressive ambition, primarily because younger House members have lower opportunity costs.

(2) Leadership position is a dummy variable that takes on the value of 1 if the member is the chair of a standing committee or a majority party leader (Speaker, majority leader, or whip).

(3) Minority party status is a dummy variable that 
takes on the value of 1 for Republican members, 0 otherwise.

(4) Ideological location in the party caucus, calculated separately for Democrats and Republicans, is their percentile rank on an underlying liberalconservative dimension derived by scaling rollcall votes with Poole and Rosenthal's (1985) NOMINATE procedure. Higher percentile rankings reflect greater conservatism.

(5) House reforms is a dummy variable intended to reflect the institutional and political changes that have been hypothesized to decrease the value of a seat in the House. It takes on a value of 1 for individuals serving in the Ninety-first and four subsequent Congresses (1969-78) but only if they had been initially elected prior to the NinetyFirst Congress.

(6) Previous vote is the percentage of the total vote the member won in the previous general election.

(7) Redistricting is a dummy variable registering the fact that a member's district had been combined with another district or had been abolished completely, with the consequence that the member must defeat another incumbent to be reelected.

(8) Scandal is a dummy variable that takes on the value of 1 if House members have been criminally indicted or charged with acts of ethical or sexual misconduct serious enough or interesting enough to have warranted coverage in the New York Times.

Variables 1 through 5 are intended to be, in one way or another, measures of how much utility or disutility members derive from their current position in the House. Variables 6 through 8 are indicators of the probability with which members succeed in being reelected.

Four more measures are of the expected benefits of seeking a Senate seat or governorship.

(9) Senate is a dummy variable reflecting the greater attractiveness of a Senate seat in comparison to a governorship. It takes on a value of 1 if the member has an opportunity to run for the Senate, 0 if the only opportunity available is for a governorship.

(10) District-to-state ratio is the log of the reciprocal of the number of congressional districts in the member's state. We take the log in order to capture the declining marginal impact of additional districts identified by Rohde.

(11) Open Senate seat is a dummy variable that takes on the value of 1 if there is an open Senate seat, 0 otherwise.

(12) Open governorship is a dummy variable that takes on the value of 1 if the incumbent governor is not seeking reelection, 0 otherwise.

An exploratory overview of these variables is provided in Table 1 , which reports mean values for members who have decided to retire, run for reelection, or seek higher office. These data derive from the

\section{TABLE}

Mean Values of Factors Affecting Congressional Career Decisions: A Comparison of Members Retiring, Running for Reelection, or Seeking Higher Office

\begin{tabular}{lccc}
\hline \multicolumn{1}{c}{ VARIABLE } & $\begin{array}{c}\text { RETIR- } \\
\text { ING }\end{array}$ & $\begin{array}{c}\text { REELEC- } \\
\text { TION }\end{array}$ & $\begin{array}{c}\text { HIGHER } \\
\text { OFFICE }\end{array}$ \\
\hline Age & 59.6 & 51.4 & 46.6 \\
Republican & .47 & .41 & .50 \\
Chair/Leader & .09 & .05 & .01 \\
Relative conservatism & & & \\
$\quad$ Democrat & .61 & .50 & .43 \\
Republican & .54 & .50 & .49 \\
Institutional reform & .21 & .13 & .16 \\
Previous margin & .71 & .70 & .67 \\
Scandal & .03 & .01 & .00 \\
Redistricting & .03 & .01 & .04 \\
Senate election & .31 & .32 & .76 \\
District-to-state-ratio & .11 & .12 & .27 \\
Open seat & & & \\
Senate & .11 & .10 & .35 \\
Governor & .31 & .30 & .43 \\
N & 386 & 7,730 & 237 \\
\hline
\end{tabular}

choices made by incumbent members of the House of Representatives serving in the Eightieth through Ninety-Ninth Congresses. Following the coding scheme developed by Loomis (1991), those who resigned or who left the House at the end of a Congress and either quit politics or took a demonstrably lesser political position (e.g., small town mayor, city council member, small town judge, member of the state legislature, appointee to a lesser federal or state position) were considered to have retired. ${ }^{6}$ As indicated earlier, the only higher offices we consider are Senate seats and governorships. A few members left to seek an office that was arguably superior to a House seat, such as president or vice-president, mayor of a large city, state attorney general, or state supreme court justice. The number of such cases is far too small to permit systematic analysis of them, so we simply excluded them. The only others cases we excluded were instances in which a member was expelled from the House, appointed to another office, or died in office. Finally, because the model we subsequently estimate requires that the alternatives under consideration be mutually exclusive, we adopt the decision of previous studies not to consider odd-year races for governor, since members need not surrender their House seats to compete in them.

The entries in this table are consistent with a number of the hypotheses discussed. Those departing to seek higher office are on average much younger than retirees, and in fact are a good deal younger than the average House member seeking reelection. In keeping with the findings of Gilmour and Rothstein (1993) and Schansberg (1992), we see that nearly half of those voluntarily leaving the House are Republicans, compared to a little more than $40 \%$ of the incumbents running for reelection 
during this period. Also in line with their findings is the fact that Republicans appear to be even more overrepresented in the ranks of those seeking higher office than among retirees. The fact that retirees are much more likely than average to be a committee chair or party leader is no doubt a function of their age. Virtually no one gave up such a position to run for higher office. Mean values of the ideological rankings indicate that liberal Democrats are more inclined to seek higher office but that conservative Democrats exhibit a greater propensity to retire. In contrast, ideological position in the party caucus appears not to matter in the career decisions of House Republicans. Hibbing's (1982) findings are also supported by our data in that incumbent representatives who lived through the reforms of the early 1970s exhibit a greater propensity to retire-and, perhaps, a greater propensity to seek higher office as well.

Table 1 shows that the typical House incumbent won the previous election by a very large margin. The size of this margin, however, appears to have little bearing on a representative's career decisions. Being redistricted out of a seat is a rare occurrence, but those who fall victim to this outrageous fate are more likely to retire or seek higher office. Not all voluntary departures, it would seem, are all that voluntary. Being the object of a scandal is also associated with a greater propensity to retire, but we observe no instance in which a scandal-plagued incumbent abandoned his seat in the House in order to run for higher office. The entries concerning the opportunity-forhigher-office variables are all consistent with previous research. Incumbent House members find the prospect of being a senator more attractive than that of being a governor. Members of the House also seem to be able to discern a good shot at a Senate seat or governorship when they see one. Those from smaller states are considerably more likely to make a run for higher office, and running for an open seat is a much more attractive prospect than running against an incumbent of the other party.

The findings in Table 1, of course, are suggestive at best. A real test of our career decision model and the various hypotheses flowing from it requires estimation of the logit model outlined previously. As noted, many members do not have an opportunity to run for higher office, which we deem to exist only if an election is being held in the member's state for a Senate seat or for the governorship and an incumbent of the member's same party is not seeking reelection to the office in question. For this reason, we estimate separate models for those individuals having all three choices and for those whose choices are confined to retire or run for reelection. The two-choice model omits the three dummies that reflect the nature of the opportunities for higher office, which necessarily take on the value of zero for all members of this class. Keep in mind that for members without an opportunity for higher office, the estimated coefficients reflect the impact of the independent variables on the unconditional probability of choosing one option over the other. For the large majority of members who do have the option to run for higher office, the estimates refer to the conditional probability of choosing one option over the other, given that the third option was not chosen. For the sake of brevity and readability we do not repeatedly refer to this fact in our discussion of the analysis.

Results of the logit estimation for members with all three choices and for those with only two are reported in Tables 2 and 3, respectively. Turning first to Table 2, each pair of columns reports the coefficients and standard errors for each possible pairwise choice: $\beta_{1}-\beta_{2}$, retire versus run for reelection; $\beta_{3}-\beta_{2}$, seek higher office versus run for reelection; and $\beta_{3}-\beta_{1}$, seek higher office versus retire. Note again that all independent variables are specified for each alternative. As indicated earlier, the number of House incumbents who ran for higher office in the face of a serious scandal was zero. As a result, the estimated variances explode, and for that reason we do not report coefficients for the scandal variable where the choice of seeking higher office is available.

We see from column 1 that when it comes to choosing between seeking reelection and retiring, most of the results echo the differences in mean values reported in Table 1 and thus tend to support Hibbing's (1982) hypotheses concerning voluntary retirement. Increasing age encourages members to retire, as does being involved in a serious scandal. The figures in Table 2 also indicate that House Republicans, conservative Democrats (so much for the rational expectations hypothesis), and members who experienced the institutional reforms of the $1970 \mathrm{~s}$ were more likely to favor retirement over running for reelection. To the extent that the lower chamber serves as a farm club for the upper, the stronger tendency of liberal Democrats to run for the Senate (and to win) may contribute to what Poole and Rosenthal (1984) describe as the ideological polarization of the U.S. Senate.

The more remarkable findings in this column; however, may be the null findings-that is, the findings where effects associated with the variables are too small to reject the hypothesis that they are actually zero. Despite the problems that a low margin of victory in the previous election might portend for future electoral prospects, it appears that this does not generally persuade incumbent congressmen to go gently into that good night. Neither, surprisingly, does losing one's seat to redistricting. Nor does there appear to be any relationship between the possession of a committee chair or party leadership position and the conditional probability of retiring. The -.15 coefficient is in the expected direction but statistically indistinguishable from zero. ${ }^{7}$

This last finding suggests to us that for most members, a seat in the House is in itself so valuable that any increase in utility derived from a committee or party leadership position is in an area of their utility function where marginal returns are rapidly diminishing. This naturally calls into question the argument that Republicans are more likely to leave the House (either by retiring or by running for higher 


\section{TABLE 2}

Analysis of Congressional Career Decisions, 1947-1986: Members With an Opportunity for Higher Office

\begin{tabular}{|c|c|c|c|}
\hline VARIABLE & $\begin{array}{c}\text { RETIRE VS. } \\
\text { RUN FOR } \\
\text { REELEC- } \\
\text { TION }^{a}\end{array}$ & $\begin{array}{c}\text { SEEK } \\
\text { HIGHER } \\
\text { OFFICE VS. } \\
\text { RUN FOR } \\
\text { REELEC- } \\
\text { TION }^{b}\end{array}$ & $\begin{array}{c}\text { SEEK } \\
\text { HIGHER } \\
\text { OFFICE } \\
\text { VS. } \\
\text { RETIRE }^{c}\end{array}$ \\
\hline Constant & $\begin{array}{c}-8.52^{\star \star} \\
(.81)\end{array}$ & $\begin{array}{l}1.20 \\
(.67)\end{array}$ & $\begin{array}{l}9.73^{\star \star} \\
(1.04)\end{array}$ \\
\hline Age & $\begin{array}{l}0.77^{\star \star} \\
(.007)\end{array}$ & $\begin{array}{r}-.04^{\star \star} \\
(.008)\end{array}$ & $\begin{array}{c}-.12^{\star \star} \\
(.01)\end{array}$ \\
\hline Republican & $\begin{array}{l}.89^{\star \star} \\
(.32)\end{array}$ & $\begin{array}{c}-.49 \\
(.28)\end{array}$ & $\begin{array}{c}-1.38^{\star *} \\
(.42)\end{array}$ \\
\hline Chair/leader & $\begin{array}{l}-.15 \\
(.28)\end{array}$ & $\begin{array}{l}-.87 \\
(.73)\end{array}$ & $\begin{array}{c}-.72 \\
(.78)\end{array}$ \\
\hline \multicolumn{4}{|c|}{ Relative conservatism } \\
\hline Democrat & $\begin{array}{l}1.40^{\star \star} \\
(.39)\end{array}$ & $\begin{array}{c}-1.23^{\star \star} \\
(.39)\end{array}$ & $\begin{array}{c}-2.63^{\star \star} \\
(.55)\end{array}$ \\
\hline Republican & $\begin{array}{l}.05 \\
(.35)\end{array}$ & $\begin{array}{l}.18 \\
(.35)\end{array}$ & $\begin{array}{l}.12 \\
(.49)\end{array}$ \\
\hline $\begin{array}{l}\text { Institutional } \\
\text { reform }\end{array}$ & $\begin{array}{l}.37^{*} \\
(.18)\end{array}$ & $\begin{array}{l}.42^{*} \\
(.20)\end{array}$ & $\begin{array}{l}.05 \\
(.26)\end{array}$ \\
\hline Previous margin & $\begin{array}{l}-.01 \\
(.005)\end{array}$ & $\begin{array}{l}-.001 \\
(.004)\end{array}$ & $\begin{array}{l}(.008) \\
(.007)\end{array}$ \\
\hline Scandal & $\begin{array}{l}2.05^{\star \star} \\
(.44)\end{array}$ & - & - \\
\hline Redistricting & $\begin{array}{l}.16 \\
(.53)\end{array}$ & $\begin{array}{l}1.75^{\star \star} \\
(.38)\end{array}$ & $\begin{array}{l}1.59^{\star} \\
(.63)\end{array}$ \\
\hline $\begin{array}{l}\text { District-to-state } \\
\text { ratio }\end{array}$ & $\begin{array}{c}-.11 \\
(.09)\end{array}$ & $\begin{array}{l}.94^{\star *} \\
(.095)\end{array}$ & $\begin{array}{l}1.05^{\star \star} \\
(.12)\end{array}$ \\
\hline Senate election & $\begin{array}{l}-.11 \\
(.17)\end{array}$ & $\begin{array}{l}1.10^{\star *} \\
(.20)\end{array}$ & $\begin{array}{l}1.21^{\star \star} \\
(.26)\end{array}$ \\
\hline $\begin{array}{l}\text { Open Seat } \\
\text { Senate }\end{array}$ & $\begin{array}{l}.21 \\
(.20)\end{array}$ & $\begin{array}{l}.82^{\star \star} \\
(.16)\end{array}$ & $\begin{array}{l}.61^{*} \\
(.26)\end{array}$ \\
\hline Governor & $\begin{array}{c}-.18 \\
(.15)\end{array}$ & $\begin{array}{l}.35^{*} \\
(.15)\end{array}$ & $\begin{array}{l}.53^{*} \\
(.21)\end{array}$ \\
\hline
\end{tabular}

Note: Only members with an opportunity for higher office are included. Standard errors are in parentheses. Initial log-likelihood is -5,407.4; at convergence, $-1,573.4 . N=4,922$.

${ }^{a} \beta_{1}-\beta_{2}$.

${ }^{b} \beta_{3}-\beta_{2}$.

$\beta_{3}-\beta_{1}$

*Significant at .05 level.

**Significant at .01 level.

office) because they are frozen out of leadership positions. Perhaps it is also the case that the rewards of holding such positions, especially for older members, must be weighed against the costs of a heavierthan-normal work load and set of responsibilities. Presumably, an aging member could always choose to resign a committee chair while remaining in the House (a sort of chairman emeritus), but we are aware of no one who has done so voluntarily. What- ever the case, this finding runs contrary to the popular image of geriatric committee chairmen hanging around, long into their dotage, to retain their coveted prize as long as possible. Perhaps congressional observers have fallen prey to something of a perceptual bias. Because it takes many terms of service in the House to advance up the seniority ladder and become chairman of a committee, most committee chairmen re pretty old. But this does not mean that most old iembers are chairmen. And once age, party, and several other factors are taken into account, possession of a committee or party leadership position does not appear to encourage members to put off retirement any longer than they would have otherwise. ${ }^{8}$

Turning to the coefficients in column 2 showing effects on the choice between running for reelection versus seeking higher office, we see that Rohde's findings concerning the structure of opportunities for higher office are strongly supported. Members from smaller states are considerably more likely to make a run for higher office. Running for an open seat is a much more attractive prospect for House members than running against an incumbent governor or Senator of the other party, and the large size of the Senate election dummy also coincides with Rohde's finding that members of the House are much more likely to be attracted by a shot at the Senate than by a governorship. Although members who are redistricted out of their seats appear no more likely to choose retirement, they are more likely to seek higher office. ${ }^{9}$ Older members are relatively less likely to seek a Senate seat or governorship, while liberal Democrats and those who were in office during the reforms of the early 1970 s are more likely. The sign of the coefficient associated with the chair/leader dummy is consistent with the hypothesis that House leaders are less likely to seek higher office, but the coefficient does not achieve conventional levels of statistical significance.

These findings are thus broadly consistent with the patterns observed in Table 1 and in previous research. This is not true of our findings concerning House Republicans. Our estimates indicate that they were no more likely than Democratic members to seek higher office rather than run for reelection. (The negative sign of the coefficient is actually in the opposite direction of that predicted.) This is contrary to what Gilmour and Rothstein (1993) observe, namely, that the higher rate of Republican departures from the House is almost entirely due to greater progressive ambition. One possible reason for this discrepancy is that our analysis extends much farther back into time than theirs. Specifically, our data series includes a period (the late 1940s and early 1950s) when the Republicans actually controlled the House for a couple of Congresses and so had not yet been relegated to "permanent minority" status. We therefore modified the Republican party dummy variable to take on the value of 1 only after the 1958 election, figuring that it was about then that the Republicans began abandoning all realistic hope of retaking the House in the foreseeable future. This change moved 
the estimated coefficient in the predicted (positive direction), but only by a small amount.

We therefore think that the major reason for the difference between our findings and those of Gilmour and Rothstein is due not to differences in our data series but rather to the fact that we control for a broad range of other variables in which there are differences between Republican and Democratic House members. First, it should be remembered that the zeroorder comparisons in Table 1, which are based upon our entire data series but do not control for these other factors, echo their finding of greater progressive ambition among Republicans. We also find that during the period of our study Republicans were about $10 \%$ less likely than Democrats to be blocked by an incumbent governor or senator of their own party. Republican members also tended to come from states with smaller congressional delegations and were somewhat more likely to be redistricted out of their seat. All these factors would predispose Republicans to higher rates of progressive ambition. We think that age differences also worked in this direction, but here, the difference in data sets does matter. Although there is no discernible difference between the average age of Republican and Democratic members in our data series, during the time frame of Gilmour and Rothstein's study Republicans were nearly two years younger on average than Democrats.

As indicated earlier, studies of congressional career decisions typically focus on one of two binary choices-retire versus run for reelection or seek higher office versus run for reelection. In an analysis of "congressional quits," Schansberg (1992) examines the third possible choice pair, retire versus seek higher office. Our analysis of the conditional probability of choosing to seek higher office versus retire is reported in Table 2, column 3. The coefficients and standard errors were obtained by estimating the model with the first alternative, retirement, as the base of normalization. It can be seen that each coefficient here necessarily equals the coefficient in column 2 minus the corresponding coefficient in column 1 . We see here that the probability of choosing to retire rather than seek higher office was dramatically higher for older members, for Republicans, and for conservative Democrats. In contrast, favorable values on the opportunity variables (district-to-state ratio, Senate election, and the two open-seat variables) predisposed members to make the opposite choice.

A possibility that occurred to us while undertaking this analysis was that congressional career decisions might be modeled more accurately by a tree structure. In our introduction, we described the hypothetical situation of a member who, having decided to leave the House, was choosing between running for the Senate or getting out of politics entirely. Alternatively, members may first decide whether to run for higher office or not and if not, then decide whether to seek reelection or to retire. If decisions follow such a tree structure (i.e., one prior choice followed by a choice between two "similar" alternatives), then a model that specifically allows for correlation between

\section{TABLE 3}

Analysis of Congressional Career Decisions, 19471986: Members With No Opportunity for Higher Office (Retire vs. Run for Reelection)

\begin{tabular}{lcc}
\hline \multicolumn{1}{c}{ VARIABLE } & $\begin{array}{c}\text { COEFFICIENT } \\
(\alpha 1-\alpha 2)\end{array}$ & S.E. \\
\hline Constant & $-9.01^{\star \star}$ & .89 \\
Age & $.07^{\star \star}$ & .01 \\
Republican & $1.01^{\star \star}$ & .39 \\
Chair/leader & -.23 & .29 \\
Relative conservatism & & \\
$\quad$ Democrat & $1.54^{\star \star}$ & .43 \\
Republican & .40 & .44 \\
Institutional reform & .21 & .21 \\
Previous margin & -.001 & -.01 \\
Scandal & $1.90^{\star \star}$ & .61 \\
Redistricting & $1.54^{\star \star}$ & .44 \\
District-to-state-ratio & -.01 & .1
\end{tabular}

Note: Only members with no opportunity for higher office are included Choice is between retiring and running for reelection. Initial loglikelihood is $-2,378.2$, at convergence, -607.3 . $N=3,431$.

"Significant at .05 level.

**Significant at .01 level.

the error terms of the two alternatives (e.g., a nested logit model) may be appropriate. We estimated such models but found that the similarity parameters were outside of the admissible range for proper probability choice models.

The results of our logit analysis for House members whose career choices were confined to either running for reelection or retiring are reported in Table 3 . For the most part, the coefficients reported here are indistinguishable from the coefficients in the corresponding $\beta_{1}-\beta_{2}$ column in Table $2 .{ }^{10}$ There is one crucial exception, namely, the case of the redistricting variable. In contrast to the tiny .16 coefficient in Table 2 , the 1.54 coefficient reported here is quite large and statistically significant. We see, then, that House incumbents who have been redistricted out of their seats are far more likely than other House members to seek higher office when that option is available but no more likely to retire. Retirement is chosen with a much higher probability than usual, however, when the opportunity to seek higher office does not exist. In our view, this finding illustrates better than perhaps any other the importance of analyzing all congressional career options simultaneously.

\section{CALCULATION OF UNCONDITIONAL CHOICE PROBABILITIES}

Although some of the findings reported in Table 2 are new, the analysis reported there does not take us much beyond previous research on voluntary retirement and on progressive ambition. As in prior studies, the coefficients register only the effect of the independent variables upon conditional choice probabilities in the various pairwise comparisons. As we 
have argued, however, a deeper understanding of congressional career decisions requires us to go beyond the separate consideration of binary choices. The real value of the logit analyses we have undertaken is that the results allow us to estimate effects of key variables upon the unconditional probability of selecting among the three options retire, run for reelection, and seek higher office. To do this, we need to compute the elasticities of the choice probabilities. This is the percentage change in the probability of selecting a particular choice (holding other variables constant), given a percentage change in an independent variable-that is,

$$
\frac{\partial \log P}{\partial \log P}=\frac{\partial P}{\partial x} \frac{x}{P} .
$$

For dummy variables, we need to calculate the percentage change in choice probabilities with respect to the change from 0 to 1 , holding other variables constant. The average effects on choice probabilities of all independent variables with statistically significant coefficients in Table 2 are reported in Table 4. (These were computed only for members with all three choices available.)

Note that proper interpretation of the elasticities requires taking into account the typical probabilities associated with each choice and the range of the independent variables. For example, the 3.89 elasticity of $P_{3}$ with respect to a change in the redistricting dummy from 0 to 1 implies a $389 \%$ increase in the probability of seeking higher office, say from a typical value of $3 \%$ to over $14 \%$. In contrast, the -.15 elasticity of $P_{2}$ with respect to the same variable implies that being redistricted out of their seat decreases the probability of incumbents running for reelection from perhaps $92 \%$ down to $78 \%$.

Table 4, row 1 (pertaining to the age variable) clearly illustrates the difference this makes in the nature of the inferences we draw from the data on congressional career decisions. Recall from Table 2 that the younger the members, the higher the conditional probability that they choose to run for reelection versus retire. But this does not mean that they have a significantly higher unconditional probability of remaining in the House. As we also know from Table 2 , younger members were also more likely to abandon the House in order to seek higher office. The resultant elasticity of $P_{2}$ (choosing to run for reelection) with respect to age of -.09 implies that a $20 \%$ increase in a member's age (e.g., from 50 to 60) lowers their probability of seeking reelection by a negligible $1.8 \%$ (e.g., from $94 \%$ to $92.3 \%$ ). Given the strong effect of age upon the conditional probability of retiring, voters in congressional elections might be persuaded to vote for younger candidates in the belief that they would have a greater likelihood of eventually becoming a party or committee leader. That age has little effect upon the unconditional probability of choosing to run for reelection, however, implies that it makes little sense for voters to practice this sort of age discrimination.

\section{TABLE 4}

Effects of Key Independent Variables Upon Unconditional Choice Probabilities

\begin{tabular}{lrrr}
\hline \multicolumn{1}{c}{ VARIABLE } & \multicolumn{3}{c}{ RETIR- REELEC- HIGHER } \\
\hline Age & \multicolumn{1}{c}{ ING } & TION & OFFICE \\
Republican & 3.70 & -.09 & -2.52 \\
Relative conservatism (D) & 1.37 & -.04 & -.04 \\
Institutional reform & .40 & -.01 & -.36 \\
Scandal & 5.12 & -.04 & .45 \\
Redistricting & .01 & -.15 & -.20 \\
District-to-state ratio & -.04 & -.04 & .89 \\
Senate election & -.05 & -.05 & 2.54 \\
Open seat & & & \\
$\quad$ Senate & -.06 & -.06 & 1.11 \\
$\quad$ Governor & -.01 & -.01 & .39 \\
\hline
\end{tabular}

Note: For the age, relative conservatism, and district-to-state ratio variables, the entry reported in this table is the percentage change in the unconditional probability of selecting a particular choice (holding other variables constant) given a percentage change in the independent variable. For the rest of the variables, which are all dummies, the entry is the percentage change in the unconditional probability of selecting a particular choice with respect to the change from zero to one in the independent variable. $N=4,922$.

The effects of a member's ideological position in the Democratic Caucus operate in a similar manner. As indicated in Table 2, conservative Democrats are more likely than liberal Democrats (all other things constant) to choose to retire rather than run for reelection. But because liberal Democrats are more likely to run for higher office, the effect of ideological position upon the unconditional probability of running for reelection is practically zero.

As it turns out, the only variables that do have a dramatic (negative) effect on the unconditional probability of choosing to run for reelection are the scandal and redistricting variables. While redistricting dramatically increases the probability of choosing to seek higher office, the major impact of scandal is to make retirement a much more attractive option. The figures in Table 4 also confirm that Republicans differ from Democrats primarily in their greater propensity to choose retirement, and are only slightly less likely to run for either reelection or higher office. Continuing down the table, we see that favorable values of the variables registering the nature of the opportunities for higher office obviously exert a strong impact upon $P_{3}$. Interestingly, the effects of the variables reflecting the nature of available opportunities for higher office, though small, are virtually identical for $P_{1}$ and $P_{2}$. We saw in Table 2 that these opportunity variables did not affect the conditional probability of choosing to retire versus running for reelection to the House. It is hard to see why they should. To the extent that such variables increase the probability of House members seeking higher office, however, they necessarily decrease the probability of choosing the subset of $\{$ retire, reelection $\}$ and thus necessarily decrease the probability of retiring. 


\section{CONCLUSION}

Many of the results produced in our analysis support those of previous researchers. In the case of the choice between retiring and running for reelection, for example, we find clear support for Hibbing's (1982) hypotheses about the greater likelihood of conservative Democrats, Republicans, and members who had experienced the reforms of the early 1970s to choose retirement. We also find consistent support for Rohde's (1979) hypotheses about the effect of the opportunity structure confronting House incumbents upon their probability of choosing to run for higher office, rather than for reelection to the House. However, our results, especially those concerning the unconditional probability of members choosing either to run for reelection, seek higher office, or retire, shed some new light onto the nature of congressional career decisions. Notably, we find that knowing the age of a member of the House tells you virtually nothing about the likelihood that he or she will run for reelection, that formal committee and party leadership positions and previous vote margins do not appear to figure into House members' career decisions, and that House Republicans exhibit no higher a level of progressive ambition than do Democrats. Finally, the interrelatedness of congressional career options is seen particularly clearly in the decisions made by those incumbents who had the dubious distinction of being redistricted out of their seats. When they had an opportunity to run for higher office, they were inclined to take it. Only when they lacked such an opportunity were they more likely than other members to opt for retirement.

We would like to conclude with a number of observations concerning the implications of our findings and to point to what we think are some potentially fruitful avenues for future research. The first issue we would raise is an econometric one. In our data, individual members are sampled every Congress in which they serve in the House. It is therefore likely that some degree of autocorrelation in the errors of the expected utility functions is present. The fact that the cross-sectional sample size is far larger than the number of repetitions (the data set includes nearly two thousand different individuals, who on average serve only about five terms) probably serves to alleviate this problem but does not eliminate it. We expect that the performance of the model would be improved if information about the error structure were explicitly incorporated. Developing a theoretically sound model that does this and that remains computationally feasible is a high priority for future research.

As indicated earlier, in an era in which very few incumbents stumble at the polls, it is the joint effects of progressive ambition and voluntary retirement that largely determine the composition of the House of Representatives. In understanding the impact of these career decisions upon the nature of the House membership, it should also be realized that the effects of these decisions are cumulative. Figure 3 illustrates
FIGURE 3

\section{Individual Career Choice and House Membership Composition}
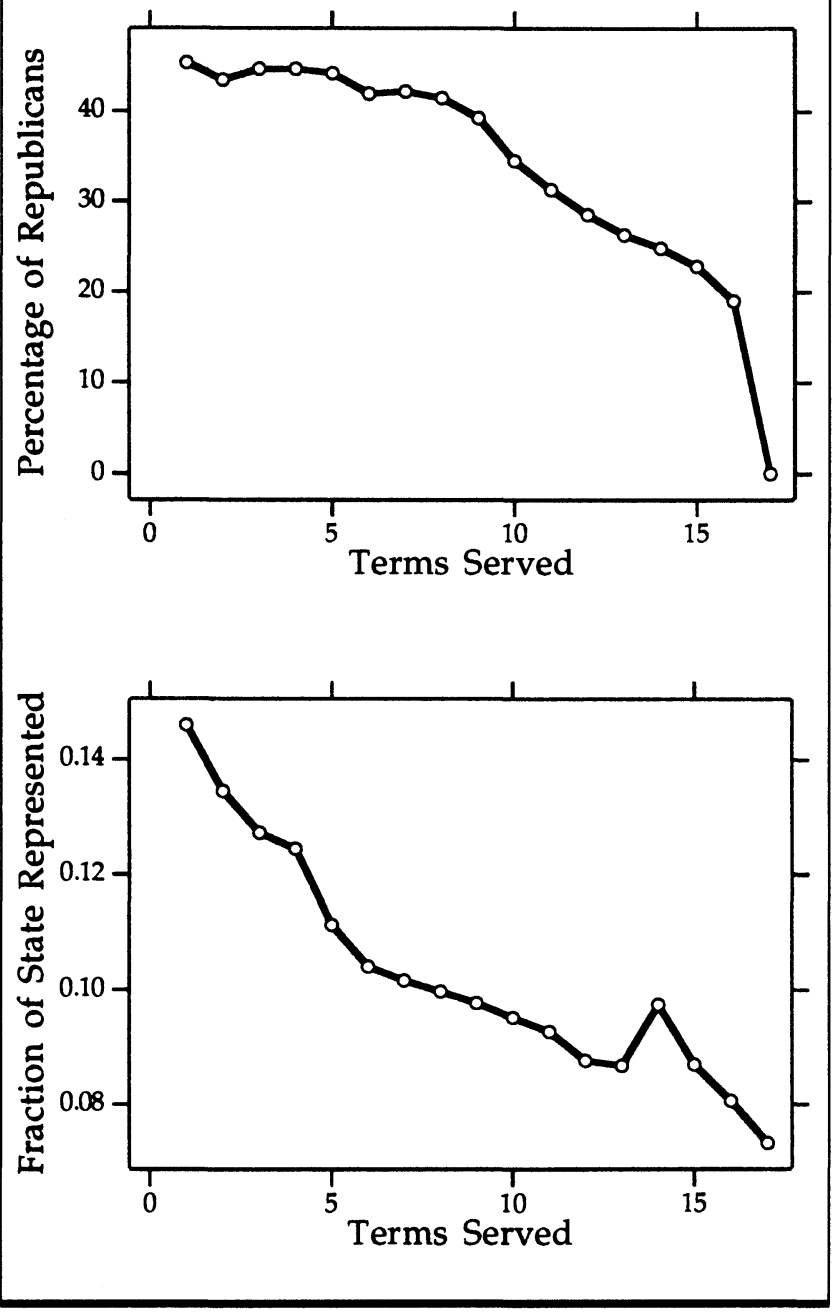

the impact that differential patterns of voluntary departure have had upon the seniority structure of the House. In the ranks of the most senior House members-the careerists, as Bullock calls themRepublicans and members from small states are few and far between. What difference does this make? Plenty, we think. Even in the House of today, more senior members are more effective legislators. They enjoy higher rank on committee, have more legislative experience, more policy expertise, more "chits" collected from past bargains made with fellow legislators, and more and better contacts in the executive branch and in the agencies. Districts in small states or those that have elected a Republican are more likely to be represented by a relatively junior incumbent, lacking, to some degree, in both experience and connections.

Finally, it is probably incumbent upon us to say something about the record number of voluntary departures from the House in 1992. There is at least one new wrinkle present. As Moore and Hibbing 
(1991) observe, 1992 was the last year that incumbents could convert leftover campaign funds into cash; according to their figures, 13 of the incumbents announcing their retirement this year had in excess of two hundred thousand dollars of convertible campaign funds. Groseclose and Krehbiel (1993) confirm that this "golden parachute" induced a large number of retirements. The factors identified in our model, however, account fairly well for the 1992 surge in retirement. Although not all of them were serious enough to satisfy our definition of a scandal, the furor involving their overdrafts at the House bank undoubtedly encouraged several other members to opt out (Jacobson and Dimock 1993). Nineteen NinetyTwo also followed a decennial census year, so the number of "voluntary" departures was boosted even more by the inevitable casualties of redistricting. Indeed, Katz cites redistricting as the "single biggest reason that more members are retiring now than in previous years $(1992,851)$. Finally, we agree with Cover (1983) that it is best not to make too much of sudden shifts in the number of members voluntarily departing the House. What goes down must eventually come back up. After a number of Congresses with lower-than-usual amounts of turnover, the resultant increase in the "fleet age" of the membership necessarily portends a higher-than-usual number of retirements somewhere down the line. The last three Congresses, of course, had witnessed quite low numbers of both voluntary departures and defeats.

\section{Notes}

An earlier version of this paper was presented at the 1992 annual meeting of the Midwestern Political Science Association, Chicago. We would like to thank Keith Poole, Michael Loomis, and Jonathan Katz for their generous assistance and Paul Brace, John Gilmour, David Grether, John Hibbing, Morgan Kousser, Forrest D. Nelson, Peter Ordeshook, Paul Rothstein, Tom Palfrey, and Tom Schwartz for their comments and criticisms.

1. It should be noted that there have recently appeared a couple of studies that look at both voluntary retirement and progressive ambition, instead of only one or the other (Gilmour and Rothstein 1993; Schansberg 1992).

2 . Note that the mother logit model is very general. In contrast, the standard logit model with a probability expression like equation 3 assumes that the underlying (expected) utility for alternative $i$ is $W_{i n}+\epsilon_{i n}$, where $\epsilon_{i n}$ is the stochastic part of the total utility following a type 1 extreme value distribution and that the decision maker acts so as to maximize his or her expected utility. In practical terms, the major difference between a standard logit model and a mother logit model thus lies in the interpretation and specification of $W_{i n}$. In a logit model, it is the expected utility of alternative $i$ to individual $n$ and need not depend on attributes not related to alternative $i$. In a mother logit model, however, $W_{\text {in }}=\log P_{\text {in }}^{*}$ generally depends not only on observed data relating to alternative $i$ but also on data relating to all other alternatives. The mother logit model, therefore, need not exhibit the independence-from-irrelevant alternatives property, in contrast to the standard logit model (Train 1986, 22).

We should note, however, that the desirable generality of the mother logit model is accompanied by difficulty in opera- tionalizing the $W_{\text {in }}$ s. Lacking information about the functional forms of the true probabilities, functional forms of $W_{i n} s$ are basically unknown and are subject to arbitrary assumptions. In this study, for example, we assume that they are linear in parameters in order to simplify computation. The correctness of the model depends, to a large extent, on the correctness of this assumption. We should point out that similar problems also exist in the standard logit model. There we know that $W_{\text {in }}$ s are utilities, but in practice we rarely know the functional form of these utility functions. As here, linearity is usually assumed without much substantive justification.

3. For notational simplicity, we hereafter drop the subscript $n$ in $W_{\text {in }}$.

4. See n. 2.

5. For many years it appeared to congressional scholars that retirement rates were particularly low among southern Democrats. Bullock (1972) shows that from 1941 through 1970 the percentage of southern Democrats who were "careerists" (present for 10 or more terms) was considerably higher than the percentage among northern Democrats. According to Kiewiet and McCubbins (1991), however, this difference between northerners and southerners was entirely due to the election of 1946, in which large numbers of northern Democrats were defeated but very few southerners. They appear to regard this finding as a startling new discovery, but it turns out that Wolfinger and Heifitz Hollinger (1970) made the same observation many years ago.

6. After obtaining Loomis's data on career decisions, we checked it against other data provided to us by Jonathan Katz and by Keith Poole. We resolved any discrepancies, which turned out to be very few in number, by consulting relevant issues of the Congressional Quarterly Weekly Report, Congressional Quarterly Almanac, and the Biographical Directory of the United States Congress.

7. We also investigated the possibility that a simple dummy for committee chairs is too crude a measure, primarily because it ignores the varying expectations that members might have regarding the prospects of their eventually attaining a chairmanship. We therefore created a variable for each House Democrat which, on the basis of life-expectancy tables, registered the probability that they would outlive all other higher-ranking Democrats on their committee. In the case of members with more than one committee assignment, the highest probability was used. When this variable was substituted for the chair/leader dummy in the equations we estimated, the coefficients remained small and insignificant.

8. One possible explanation for this finding that occurred to us was that chairmen or party leaders might hold on to their positions until they died in office and thus exit the sample without ever retiring. We found, however, that death rates were no higher for committee chairmen and party leaders than for ordinary members.

9. The redistricting variable may be subject to a bit of endogeneity, in that those drawing the lines may have less compunction about eliminating the district of an incumbent House member if it is known in advance that that member is planning to retire or to run for higher office. When asked how the state would be redistricted after losing three seats in in the 1960 round of reapportionment, Stephen McCann, Democratic floor leader in the Pennsylvania House, answered, "Show me three congressmen who are willing to give up their seats" (Cooke and Keefe 1962, 150). McCann was unfortunately unable to find three such members. Since the court rulings of the $1960 \mathrm{~s}$, of course, the constraint that districts must contain virtually identical numbers of people makes it more difficult to protect all incumbents in a state or portion of a state that has lost population since the last census.

10. The similarities between $\alpha_{1}-\alpha_{2}$ and $\beta_{1}-\beta_{2}$ prompted us to estimate a model with pooled samples. This model was indistinguishable from the current model in terms of goodness-of-fit criteria. 


\section{References}

Barnes, Fred. 1988. "The Unbearable Lightness of Being a Congressman." New Republic, 15 February, 18-21.

Bauer, Monica, and John Hibbing. 1989. "Which Incumbents Lose in House Elections: A Response to Jacobson's 'The Marginals Never Vanished'." American Journal of Political Science 33:262-71.

Brace, Paul. 1984. "Progressive Ambition in the House: A Probabilistic Approach." Journal of Politics 46:556-69.

Bullock, Charles. 1972. "House Careerists: Changing Patterns of Longevity and Attrition." American Political Science Review 66:1295-1300.

Cooke, Edward, and William Keefe. 1962. "Pennsylvania: The Limits of Power in a Divided Government." In The Politics of Reapportionment, ed. Malcolm Jewell. New York: Atherton.

$\rightarrow$ Cooper, Joseph, and William West. 1981. "Voluntary Retirement, Incumbency, and the Modern House." Political Science Quarterly 96:279-300.

$\rightarrow$ Cover, Albert. 1983. "Seniority in the House: Patterns and Projections." American Politics Quarterly 11:429-40.

$\rightarrow$ Frantzich, Stephen. 1978. "Opting Out: Retirement from the House of Representatives." American Political Science Quarterly 6:251-73.

Gilmour, John, and Paul Rothstein. N.d. "Early Republican Retirement: A Cause of Democratic Dominance in the House of Representatives." Legislative Studies Quarterly. Forthcoming.

Groseclose, Tim, and Keith Krehbiel. N.d. "Golden Parachutes, Rubber Checks, and Strategic Retirements from the 102nd House." American Journal of Political Science. Forthcoming.

Hain, Paul. 1974. "Age, Ambition, and Political Careers: The Middle-Age Crisis." Western Political Quarterly 27:265-74.

Hibbing, John. 1982. Choosing To Leave: Voluntary Retirement from the U.S. House of Representatives. Washington: University Presses of America.

Jacobson, Gary. 1987. "The Marginals Never Vanished: Incumbency and Competition in Elections to the U.S. House of Representatives, 1952-1982." American Journal of Political Science 31:126-41.

Jacobson, Gary, and Michael A. Dimock. 1993. "Checking Out: The Effects pf Bank Overdrafts on the 1992 House Elections." Presented at the annual meeting of the Midwest Political Science Association, Chicago.
Katz, Jeffrey. 1992. "Record Rate of Retirements Suggest Major Shakeup." Congressional Quarterly Weekly Report 85155.

Kiewiet, D. Roderick, and Mathew McCubbins. 1991. The Logic of Delegation. Chicago: University of Chicago Press.

Loomis, Michael. 1991. "The Preferences of Congressmen Matter in Floor Voting." Carnegie Mellon University. Photocopy.

McFadden, Daniel. 1975. "On Independence, Structure, and Simultaneity in Transportation Demand Analysis." Working Paper No. 7511. University of California (Berkeley) Institute of Transportation and Traffic Engineering.

Mann, Thomas. 1978. Unsafe at Any Margin. Washington: American Enterprise Institute.

Moore, Michael, and John Hibbing. 1991. "Is Serving in Congress Fun Again? Voluntary Retirements and Congressional Careers through the 1980's." University of Nebraska. Photocopy.

Peters, John, and Susan Welch. 1980. "The Effects of Corruption on Voting Behavior in Congressional Elections." American Political Science Review 74:697-708.

$\rightarrow$ Poole, Keith, and Howard Rosenthal. 1984. "The Polarization of American Politics." Journal of American Politics 46:1061-79.

Poole, Keith, and Howard Rosenthal. 1985. "A Spatial Model for Legislative Roll Call Analysis." American Journal of Political Science 29:357-84.

Rohde, David. 1979. "Risk-Bearing and Progressive Ambition: The Case of Members of the United States House of Representatives." American Journal of Political Science 23:126.

Schansberg, D. Eric. 1992. "Moving out of the House: An Analysis of Congressional Quits." Presented at the annual meeting of the Public Choice Society, New Orleans.

Schlesinger, Joseph. 1966. Ambition and Politics: Political Careers in the United States. Chicago: Rand McNally.

Squire, Peverill. 1988. "Member Career Opportunities and the Internal Organization of Legislatures." Journal of Politics 50:726-44

Train, Kenneth. 1986. Qualitative Choice Analysis: Theory, Econometrics, and an Application to Automobile Demand. Cambridge: Massachusetts Institute of Technology Press.

Varian, Hal. 1984. Microeconomic Analysis. New York: Norton.

Wolfinger, Raymond, and Joan Heifitz Hollinger. 1970. "Safe Seats, Seniority, and Power in Congress." In Congressional System, ed. Leroy Rieselbach. Belmont, CA: Wadsworth.

\section{Roderick Kiewiet is Professor of Political Science and Dean of Students, California Institute of Technology, Pasadena, CA 91125. \\ Langche Zeng is Assistant Professor of Political Science, University of Oregon, Eugene, OR 97403-1284.}

